\title{
Prevalence and Genotypic Characterization of Vibrio Alginolyticusin Somemarine Fishes
}

Ezzat M.*, Gihan M. O. Mohamed**, Marwa Abd El-Hak*** and Wahdan A.*

*Department of Bacteriology, immunology Mycology-Faculty of Veterinary Medicine Suez Canal University

**Department of Bacteriology Animal Health Research Institute PortSaid branch

*** Veterinarian, fish farming and technology institute Suez Canal University

\begin{abstract}
This study aimed to determine the prevalence of $\boldsymbol{V}$. alginolyticus isolated from mullet, seabream, and seabass marine fishes in addition to study the phenotypic and genotypic identification of the isolated strains. A total of 180 samples were examined bacteriologically for detection of $\boldsymbol{V}$. alginolyticus. Six isolates were identified biochemically as $\boldsymbol{V}$. alginolyticus (3. 33\%).The highest prevalence of $\boldsymbol{V}$. alginolyticuswas in seabreamfollowed bymullet and seabass in a percentage of $5.00 \% 3.33 \%$ and $1.60 \%$ respectively. The highest prevalence of $\boldsymbol{V}$. alginolyticus was isolated from liver and spleen with percentages of $50 \%$ in mullet fish. While in seabream fish the highest prevalence of $\boldsymbol{V}$. alginolyticuswas isolated fromliver andkidneywith percentages $66.67 \%$ and $33.33 \%$ respectively. On other hands the highest prevalence of $\boldsymbol{V}$. alginolyticuswas isolated fromliver of seabass fish samples in a percentage of $100 \%$. PCR was used for confirmation of Vibrio spp. by detection of $16 \mathrm{~S} r R N A$ and $\boldsymbol{V}$. alginolyticusby detection of collagenasegene.All 6 isolates were positive for the 16S rRNA andcollagenasegene which specific for $\boldsymbol{V}$. alginolyticus. All $\boldsymbol{V}$. alginolyticusisolates were tested for the detection oftdh and trhwhich is responsible for its virulence. The results showed that all $\boldsymbol{V}$. alginolyticusisolates were negative fortdh and trhgenes.
\end{abstract}

\section{Introduction}

In Egypt, fish remains a growing, vibrant and have an additionalimportance as being the main source ofanimal protein where it is available onlarge scale and in suitable prices (Edriset al., 2013). However, a major setback in aquaculture is the sudden outbreak of diseases, especially those caused by Vibrio spp., which are considered significant economic and public health problems (Abd Ell-Razeq and Khaliel, 2014).

The genus Vibrio is a gramnegative, a curved-rod shape 
bacteria that occur naturally in estuarine or marine environments, that inhabit estuarine ecosystems (Schärer et al., 2011).

Vibrio is widespread in the estuarine and coastal marine environments and show seasonal dynamics in their population (Thompson et al., 2004). In these environments, Vibrio plays a significant role in the degradation of organic matter (Damiret al., 2013) hence, regulates the dissolved organic carbon to higher trophic levels of the marine food web (Grossartet al.,2005). However, some members of the genus Vibrio are also opportunistic pathogens that have been associated with infections in humans and marine animals (Austin, 2010).

Vibriosis, an economically important disease especially in the mariculture industry, affects large number of fish and shellfish species, both cultured and feral.The genus Vibrio is a ubiquitous bacteria present in almost of aquatic and marine habitats cause infections in human (Baker-Austin et al., 2018).

Numerous studies have been conducted to determine the relationship between Vibrio spp. abundance and environmental factors such as temperature, salinity, nutrients and dissolved oxygen. As a result, these water quality characteristics can be used in a predictive manner to determine when these pathogens may be present (Khalil et al., 2014). The outbreaks of vibriosis were a common problem among cultured marine fish particularly at summer season, as a result of the deterioration of basic water parameters as temperature, $\mathrm{pH}$, dissolved oxygen, and salinity (Albert and Ransangan, 2013).

Thus with the rapid extension of the intensive mariculture and the consequent deterioration of culture condition, vibriosis is considered one of the most prominent pathogens frequently affecting a wide range of fish spp. (Alcaide, 2003).

$V$. alginolyticusis considered one of the most dangerous pathogens in marine aquaculture causing severe losses among a large numbers of fish and shellfish species (Austin and Austin, 2012). V. alginolyticus has been suggested to be a pathogen of humans (Bauer and Young, 2000).

In recent years, PCR have overcomeproblems associated with culture-based techniques, enabling the detection of bacteria directly in clinical samples without the need for previous culturing (Gonzalez et al., 2004). 
$\boldsymbol{V}$. alginolyticus was isolated during recurrent episodes of mass mortalitiesamong different stages of gilthead seabream (Sparusaurata) and Europeanseabass (Dicentrarchuslabrax) (Abdel-Aziz et al., 2013). So this study aimed to make phenotypic and genotypic identification of $\boldsymbol{V}$. alginolyticuswhichisolated from some marine fishes at different farms in Port-Said Governorates.

\section{Materials and Methods \\ Samples}

Totally 180 marine fish samples include 60 of each seabass(Dicentrarchuslabrax), seabream(Sparusaurata) and mullet (Mugilcephalus) were collected randomly from different fish farms at Port-Said governorates. Samples were taken under aseptic condition from the lesions, in the external body surface, gills, liver, kidneys, muscle, and spleen. The samples put in sterile polythene bags and transferred to the laboratory, as soon as possible, in an ice-box to be examined bacteriologically for detection of $\boldsymbol{V}$. alginolyticus.

\section{Bacteriological identification} of $V$. alginolyticus

Primary isolation was done according to (Kaysner and DePaola 2004). Loopful of culture from pellicle (surface growth) of each flask was then streaked onto TCBS agar plates and incubated at $35^{\circ} \mathrm{C}$ for $18-24$ h.5-10 yellow colonies from TCBS media suspected to be $\boldsymbol{V}$. alginolyticuswere selected randomly for characterization. Cultures examined quickly after removal from the incubator as the yellow coloration of the colonies may revert to a green color when left at room temperature. Morphological and biochemical identification of the genus Vibriowere done according to Elliot et al., (2001).

Molecular detection of $V$. alginolyticus

Extraction of DNA was done according to QIAamp DNA Mini kit (Qiagen, Germany, $\mathrm{GmbH}$ ) instructions. Preparation of PCR Master Mix was done according to Emerald Amp Max PCR Master Mix (Takara, Japan), Code No. RR310Akit. Temperature and time conditions of the primers during PCR are shown in Table (1).

Oligonucleotide primers sequences are shown in Table (2). The products of PCR were separated by electrophoresis. The gel was photographed by a gel documentation system (Alpha Innotech, Biometra) and the data was analyzed through computer software. 
Table (1): PCR conditions for detection ofVibrio spp. andV. alginolyticus and some virulence genes.

\begin{tabular}{|c|c|c|c|c|c|c|}
\hline Target gene & $\begin{array}{c}\text { Primary } \\
\text { denaturation }\end{array}$ & $\begin{array}{c}\text { Secondary } \\
\text { denaturation }\end{array}$ & Annealing & Extension & $\begin{array}{c}\text { Final } \\
\text { extension }\end{array}$ & Reference \\
\hline 16S rRNA & $\begin{array}{c}94^{\circ} \mathrm{C} \\
5 \mathrm{~min} .\end{array}$ & $\begin{array}{c}94^{\circ} \mathrm{C} \\
30 \mathrm{sec} .\end{array}$ & $\begin{array}{c}56^{\circ} \mathrm{C} \\
45 \mathrm{sec} .\end{array}$ & $\begin{array}{l}72^{\circ} \mathrm{C} \\
45 \mathrm{sec} .\end{array}$ & $\begin{array}{c}72^{\circ} \mathrm{C} \\
10 \mathrm{~min}\end{array}$ & $\begin{array}{c}\text { Tarret al., } \\
(2007)\end{array}$ \\
\hline $\begin{array}{l}\text { V. alginolyticus } \\
\text { Collagenase }\end{array}$ & $\begin{array}{c}94^{\circ} \mathrm{C} \\
5 \mathrm{~min} .\end{array}$ & $\begin{array}{c}94^{\circ} \mathrm{C} \\
30 \mathrm{sec} .\end{array}$ & $\begin{array}{c}50^{\circ} \mathrm{C} \\
40 \mathrm{sec} .\end{array}$ & $\begin{array}{l}72^{\circ} \mathrm{C} \\
45 \mathrm{sec} .\end{array}$ & $\begin{array}{c}72^{\circ} \mathrm{C} \\
10 \mathrm{~min} .\end{array}$ & $\begin{array}{c}\text { Abu-Elala } e t \\
\text { al., (2016) }\end{array}$ \\
\hline trh & $\begin{array}{c}94^{\circ} \mathrm{C} \\
5 \mathrm{~min} .\end{array}$ & $\begin{array}{c}94^{\circ} \mathrm{C} \\
30 \mathrm{sec} .\end{array}$ & $\begin{array}{c}54^{\circ} \mathrm{C} \\
30 \mathrm{sec} .\end{array}$ & $\begin{array}{c}72^{\circ} \mathrm{C} \\
30 \mathrm{sec} .\end{array}$ & $\begin{array}{l}72^{\circ} \mathrm{C} \\
7 \mathrm{~min} .\end{array}$ & \multirow[t]{2}{*}{$\begin{array}{c}\text { Mustapha } e \\
\text { al., (2013) }\end{array}$} \\
\hline$t d h$ & $\begin{array}{c}94^{\circ} \mathrm{C} \\
5 \mathrm{~min} .\end{array}$ & $\begin{array}{c}94^{\circ} \mathrm{C} \\
30 \mathrm{sec} .\end{array}$ & $\begin{array}{c}54^{\circ} \mathrm{C} \\
40 \mathrm{sec} .\end{array}$ & $\begin{array}{c}72^{\circ} \mathrm{C} \\
40 \mathrm{sec} .\end{array}$ & $\begin{array}{c}72^{\circ} \mathrm{C} \\
10 \mathrm{~min} .\end{array}$ & \\
\hline
\end{tabular}

Table (2): primers used for identification of V.Vibrio spp. andalginolyticus and some virulence genes.

\begin{tabular}{|c|c|c|c|}
\hline Target gene & $\begin{array}{c}\text { Primers sequences } \\
5^{\prime}-3^{\prime}\end{array}$ & $\begin{array}{l}\text { Amplified } \\
\text { segment } \\
\text { (bp) }\end{array}$ & Reference \\
\hline \multirow{2}{*}{ Vibrio $16 S$ rRNA } & CGGTGAAATGCGTAGAGAT & \multirow{2}{*}{$663 \mathrm{bp}$} & \multirow{2}{*}{ Tarret al., (2007) } \\
\hline & TTACTAGCGATTCCGAGTTC & & \\
\hline \multirow{2}{*}{$\begin{array}{l}\text { V. alginolyticus } \\
\text { Collagenase }\end{array}$} & CGAGTACAGTCACTTGAAAGCC & \multirow{2}{*}{737 bp } & \multirow{2}{*}{$\begin{array}{l}\text { Abu-Elalaet al., } \\
\underset{(2016)}{ }\end{array}$} \\
\hline & CACAACAGAACTCGCGTTACC & & \\
\hline \multirow{2}{*}{ trh } & GGCTCAAAATGGTTAAGCG & \multirow{2}{*}{250 bp } & \multirow{4}{*}{$\begin{array}{l}\text { Mustapha et al., } \\
\text { (2013) }\end{array}$} \\
\hline & CATTTCCGCTCTCATATGC & & \\
\hline \multirow{2}{*}{$t d h$} & CCATCTGTCCCTTTTCCTGC & \multirow{2}{*}{373 bp } & \\
\hline & CCAAATACATTTTACTTGG & & \\
\hline
\end{tabular}

\section{Results}

Table (3): Prevalence of $V$. alginolyticusin different marine fish samples

\begin{tabular}{|c|c|c|c|}
\hline \multirow{2}{*}{ Types of fish } & Examined samples & \multicolumn{2}{|c|}{ Positive V. alginolyticus } \\
\cline { 2 - 4 } & No. & No. & $\%$ \\
\hline Mullet & 60 & 2 & 3.33 \\
\hline Seabream & 60 & 3 & 5.00 \\
\hline Seabass & 60 & 1 & 1.60 \\
\hline Total & 180 & 6 & 3.33 \\
\hline
\end{tabular}


Table (4): Distribution of $V$. alginolyticus at different organs of marine fish's samples.

\begin{tabular}{|c|c|c|c|c|c|c|c|c|c|c|c|c|c|}
\hline \multirow[t]{4}{*}{ Fish samples } & \multirow{4}{*}{$\begin{array}{l}\text { No. of } \\
\text { strains }\end{array}$} & \multicolumn{12}{|c|}{ Type of samples } \\
\hline & & \multirow{2}{*}{\multicolumn{2}{|c|}{ Surface }} & \multicolumn{6}{|c|}{ Internal organs } & \multirow{2}{*}{\multicolumn{2}{|c|}{$\begin{array}{l}\text { Muscle } \\
\text { (Flesh) }\end{array}$}} & \multirow{2}{*}{\multicolumn{2}{|c|}{ Gills }} \\
\hline & & & & \multicolumn{2}{|c|}{ Liver } & \multicolumn{2}{|c|}{ Kidney } & \multicolumn{2}{|c|}{ Spleen } & & & & \\
\hline & & No. & $\%$ & No. & $\%$ & No. & $\%$ & No. & $\%$ & No. & $\%$ & No. & $\%$ \\
\hline Mullet & 2 & 0 & 0 & 1 & 50 & 0 & 0 & 1 & 50 & 0 & 0 & 0 & 0 \\
\hline Seabream fish & 3 & 0 & 0 & 2 & 66.67 & 1 & 33.33 & 0 & 0 & 0 & 0 & 0 & 0 \\
\hline Seabass & 1 & 0 & 0 & 1 & 100 & 0 & 0 & 0 & 0 & 0 & 0 & 0 & 0 \\
\hline
\end{tabular}

Table (5): Molecular identification of Vibrio spp. and V. alginolyticusin mullet, seabream andseabass.

\begin{tabular}{|c|c|c|c|c|c|c|}
\hline Genes & 1 & 13 & 22 & 24 & 26 & 37 \\
\hline $\begin{array}{c}\text { I6S rRNA } \\
\text { Genral for Vibrio spp. }\end{array}$ & + & + & + & + & + & + \\
\hline Collagenase gene for V. alginolyticus & + & + & + & + & + & + \\
\hline tdh & - & - & - & - & - & - \\
\hline trh & - & - & - & - & - & - \\
\hline
\end{tabular}

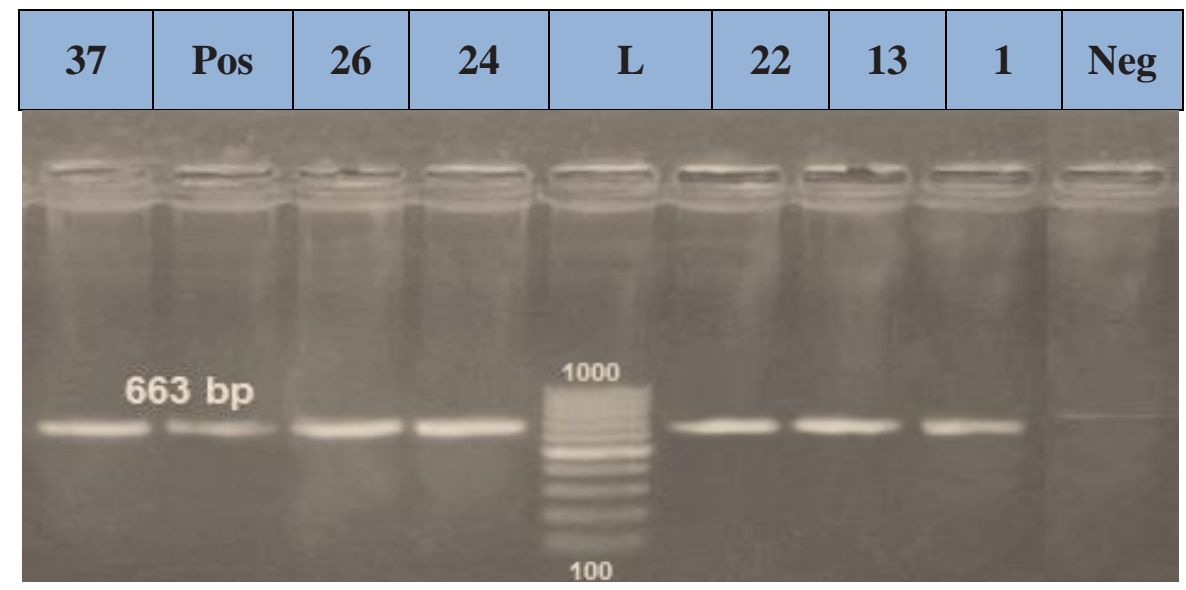

Figure (1): Agarose gel electrophoresis showed that isolates (1 and 13) from mullet fish, (22, 24 and 26) from seabream fish and (37) from seabass were positive for $16 S$ rRNAgene for Vibrio spp. at $663 \mathrm{bp}$. L = DNA ladder (100 $1000 \mathrm{bp}$ ), Pos $=$ positive control, $\mathrm{Neg}=$ Negative control. 


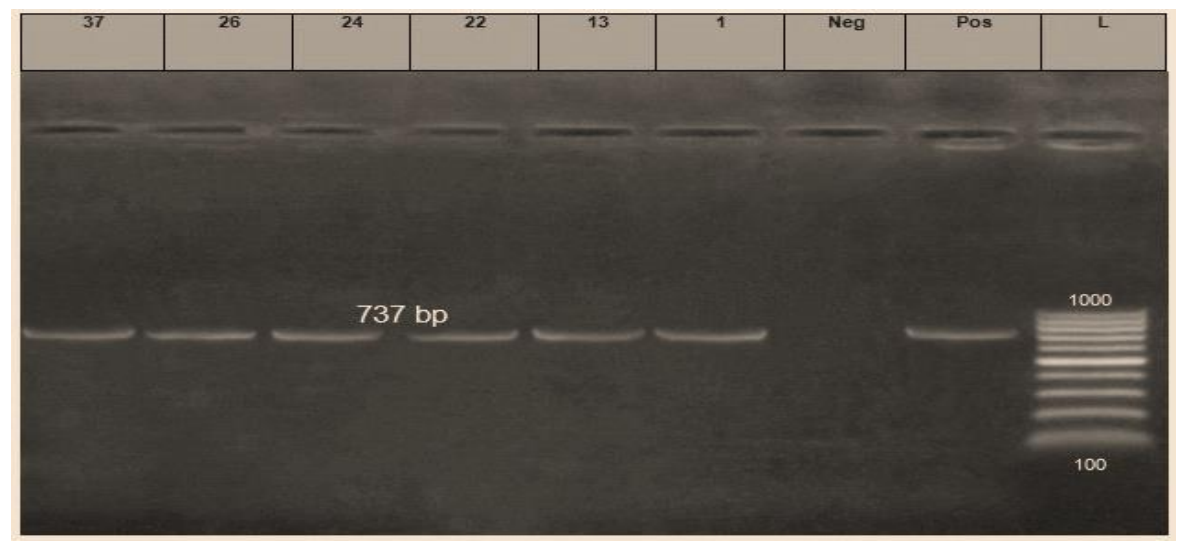

Figure (2): Agarose gel electrophoresis showed that 6 tested isolates from different marine fish samples were positive for collagenase gene $V$. alginolyticus at $(737 \mathrm{bp}) . \mathrm{L}=$ DNA ladder $(100-1000 \mathrm{bp})$, Pos = positive control, Neg = Negative control.

\section{Discussion:}

V. alginolyticusis highly abundant in marine environments, including estuaries, marine coastal waters and sediments, and aquaculture settings (Vandenbergheet al., 2003). From the public health significance $\boldsymbol{V}$. alginolyticus considered the most important species affecting human being fed on fish and crustacean meals (mustaphaet al., 2013). In Egypt, mariculture represents an important investment for fishermen, but diseases and high feeding cost are the main obstacles facing sustainability. The marine environment, which includes both native and externally introduced microbial contaminants and plays an important role in ecological and epidemiological studies as it acts as a reservoir not only for the persistence, dissemination, and evolution but also the transmission of pathogenic microbes to humans (Khalil and Abd El-Latif, 2013). The results in Table (3)shownedthat the bacteriological examination of 180 samples of marine fishes for presence of $\boldsymbol{V}$. alginolyticus. Six isolates were identified biochemically as $\boldsymbol{V}$. alginolyticus (3.33\%). The highest prevalence of $\boldsymbol{V}$. alginolyticuswas in seabream followed bymullet and seabass in a percentage of $5.00 \%$ $3.33 \%$ and $1.60 \%$ respectively.Nearly similar results were obtained bySaadet al., 2015 who isolated $V$. alginolyticusin a percentage of $4 \%$. The current results were less than Jaksicet al., 2002 whoisolated $V$. alginolyticusin a percentage of $14 \%$ and Edriset al., 2013whoisolated $\quad V$. alginolyticusin a percentage of $25.7 \%$.This difference in prevalence percentages may be related to difference in area, fish 
species, changein the fish immune system and time and methods of sampling and water quality characters.

Table (4) showed that most of $V$. alginolyticusisolates

were recovered from internal organs of examined fish samples. The highest prevalence of $\boldsymbol{V}$. alginolyticuswas isolated from liver and spleen with percentages of $50 \%$ in mullet fish. While in seabream fish the highest prevalence of $\boldsymbol{V}$. alginolyticuswas isolated fromliver andkidneywith percentages $66.67 \%$ and $33.33 \%$ respectively. On other hands the highest prevalence of $\boldsymbol{V}$. alginolyticuswas isolated from seabass fish liver in a percentage of $100 \%$. These results were agreed with (Mahmoudet al., 2017) who isolated the $\boldsymbol{V}$. alginolyticusfrom internal organs of marine fish.

The results of agarose gel electrophoresis using $16 S \quad r R N A$ gene in Table (5) and Figure (1)revealed that the all tested isolates were Vibrio strain with molecular weight 663bp. These results are approximately similar that recorded by Mohamed et al. (2017) who used $16 S$ rRNAgene sequence as accurate identification and confirmation of all tested strains and Montieriet al. (2010) who used 16S rRNA genefor confirmation of biochemically identified $\boldsymbol{V}$. alginolyticus However this gene has low discriminatory power to differentiate closely related vibrio species that has nearly identical sequences.
PCR assays were developed with specific primers for the detection collagenase which specific for $\boldsymbol{V}$. alginolyticuswas found in 6 isolatesTable (5) and Figure (2) revealed that the all tested isolates were $\boldsymbol{V}$. alginolyticus with molecular weight 737bp.The incidence of $\boldsymbol{V}$. alginolyticusisolated from mullet, seabream andseabass were 2.3 and 1 isolates respectively.All 6 isolates of $\boldsymbol{V}$. alginolyticusdid not show any virulence, as all of it showed negative detection for tdhand trh genes.Our results agree with results recorded by Mohamed et al. (2017) who identified Vibrio spp. by molecular identification using species specific primers for collagenase categorized 10 isolates belong to $\boldsymbol{V}$. alginolyticus specific detection of $\boldsymbol{V}$. alginolyticus was confirmed via collagenase gene (Miyoshi, 2013) that produce a specific and clear band at $737 \mathrm{bp}$.The results of molecular detection and determination of tdhandtrh virulence genes of $\boldsymbol{V}$. alginolyticusstrains were not detected in 6strains in the examined fish samples. Our results agree with the results recorded by Serracca et al., 2011.

References:

Abd El-Aziz, M.; Eissa, A. E.; Hanna, M. and Okada, M. A. (2013):Identifying some pathogenic Vibrio/Photobacterium species during mass mortalities of cultured Gilthead seabream (Sparus aurata) and European seabass 
(Dicentrarchus labrax) from some Egyptian coastal provinces. International Journal of Veterinary Science and Medicine, 1(2): 87- 95. Abd Ell-Razeq, G. S. and Khaliel, S. A. (2014): Molecular Characterization and Antimicrobial Susceptibility of Vibrios Isolated from Healthy and Diseased Aquacultured Freshwater Fishes. Global Veterinaria 13 (3): 397-407

Abu-Elala, N.M.; Abd-Elsalam, R.M.; Marouf, S.; Abdelaziz, M. and Moustafa, M. (2016): Eutrophication, Ammonia Intoxication, and Infectious Diseases: Interdisciplinary Factors of Mass Mortalities in Cultured Nile Tilapia. Journal of Aquatic Animal Health, 28(3):187-198.

Albert, V. and Ransangan, J. (2013): Effect of water temperature on susceptibility of culture marine fish species to vibriosis. International Journal of Research in Pure and Applied Microbiology 3(3): 48-52.

Alcaide, E. (2003): Numerical taxonomy of Vibrionaceae isolated from cultured amberjack (Serioladumerili) and surrounding water. Current Microbiology 46(3): 184-189.

Austin, B. (2010): Vibrios as causal agents of zoonoses. Vet. Microbiol., 27;140(3-4):310-317.

Austin, B. and Austin,D.A.(2012): Bacterial fish pathogens: diseases of farmed and wild fish. 5 ed.thChichester, UK: Springer/Prazis Publishing
Baker-Austin, C.; Oliver, J. D.; Alam, M.; Ali, A.; Waldor, M. K.; Qadri, F. and Martinez-Urtaza, J. (2018):Vibrio spp. infections. Nature Reviews Disease Primers,4(1): 8.

Bauer J.C. \& Young M.C. (2000): Epidermal lesions and mortality caused by vibriosis in deep-sea Bahamian echinoids: a laboratory study. Diseases of Aquatic Organisms, 39: 193-199.

Gonza'lez, S. F. ; Melissa J. K. ; Michael E. N.;Ysabel, S. and Douglas, R. C. (2004): Simultaneous Detection of Marine Fish Pathogens by Using Multiplex PCR and a DNA Microarray. Journal of clinical microbiology:1414-1419.

Damir, K.; Irena, V. S.; Damir, V. and Emin, T. (2013):Occurrence, characterization and antimicrobial susceptibility of Vibrio alginolyticus in the Eastern Adriatic Sea. Marine Pollution Bulletin, 75: $46-52$.

Edris, A.M; Fatin S. Hassanien;Hassan, M.A. and Abd Ellatif Z.A. (2013):Demonstration of vibrio species in marine fish with specialReference to vibrio parahaemolyticus. Benha veterinary medical journal, 25(2): 271-275.

Elliot, E.L.; Kaysner, A.C.; Jackson, L. and Tamplin, M.L. (2001):Vibrio cholerae, $\quad V$. parahaemolyticus, $\quad V$. vulnificusandother Vibrio spp.In: Food and Drug Administration - 
FDA, Bacteriological Analytical Manual. FDA, Center for Food Safety and Applied Nutrition CFSAN.

Grossart, H.P.; Levold, F.,; Allgaier,M.; Simon, M., and Brinkhoff, T. (2005): Marinediatom species harbour distinct bacterial communities. Environmental Microbiology, 7:860 -873.

Jaksic, S.; Uhitil, S.; Petrak, T.; Bazulic,D. and Karolyi, L.G. (2002): Occurrence of Vibrio spp. In sea fish,shrimps and bivalve molluscs from theAdriatic Sea. Food Control, 13: 491-493.

Kaysner, C. A. and DePaola, A. (2004): Bacteriological Analytical Manual Online, (Ed. G. J.Jackson, R. I. Merker, and R. Bandler), Center for food safety and applied nutrition, U.S. Food and Drug Administration, May 2004, Ch. 9.

Khalil, R.H. and Abd El-Latif, H.M., (2013): Effect of Vibrio alginolyticus on Mugilcapito. J. Arabian Aquacult. Soc., 8(1): 193204.

Khalil, S. A.; Abou-Akkada, A. S. and Samia, M. (2014): MolecularStudies on vibrio Species Isolated from imported frozen fish. GlobalVeterinaria, 12(6): 782-789.

Miyoshi, S. (2013):Extracellular proteolytic enzymes produced by human pathogenic Vibrio species. Front. Microbiol., 4: 339.

Mohamed, A.; Mai, D. I.; Marwa, A. I.; Nermeen, M. A. and Dalia, A. A. (2017): Monitoring of different Vibrio species affecting marine fishes in
Lake Qarun and Gulf of Suez: Phenotypic and molecular characterization.Egyptian Journal of Aquatic Research, 43(2): 141-146. Mahmoud, S. A.; El-Bouhy, Z. M.; Hassanin, M. E. and Fadel, A. H. (2017):Vibrio alginolyticus and Photobacterium damselae subsp. Damselae: Prevalence, Histopathology and Treatment in seabass Dicentrarchus labra. Journal of Pharmaceutical, Chemical and Biological Sciences, 5(4): 354-364.

Montieri

,S. ; Suffredini, E.; Ciccozzi,M. an d Croci, L. (2010): Phylogenetic andevolutionary analysis of Vibrio parahaemolyticus and Vibrio alginolyticus isolates based on toxR gene sequence. New Microbiol., 33 ; 359-372.

Mustapha, S.; Mustapha, E.M. and Nozha, C. (2013):Vibrio Alginolyticus: An Emerging Pathogen of Foodborne Diseases. International Journal of Science and Technology, 2 (4): 302-309.

Saad, M. S.; Maha, M. S. and Hania, E. A.E. (2015): Incidence of Vibrio species in fish with special emphasis on the effect of heat treatments. Benha veterinary medical journal, 2 9(1): 38-44

Schärer, K.; Savioz, S.; Cernela, N.; Saegesser, G. and Stephan, R. (2011): Occurrence of Vibrio spp. in fish and shellfish collected from the Swiss market. J Food Prot., 74(8): 1345-7.

Serracca, L.; Battistini, R.; Rossini, I.; Prearo, M.; Ottaviani, 


\section{D.; Leoni, F. and Ercolini, C. Thompson, F. L.; Lida, T.; and (2011): Vibrio virulence genes in Swigs, J. (2004): Biodiversity of fishes collected from estuarine Vibrios. Microbiology and waters in Italy. Lett Appl Molecular Biology Reviews., 68(3): Microbiol.,53(4): 403-8. 403-431.}

Tarr, C. L.; Patel, J. S.; Puhr, N. D.; Sowers, E. G.; Bopp, C. A. and Strockbine, N. A. (2007): Identification of Vibrio isolates by a multiplex PCR assay and rpoB sequence determination. Journal of Clinical Microbiology, 45(1): 134-

Vandenberghe, J.; Thompson, F. L.; Gomez-Gil, B. and Swings, J. (2003): Phenotypic diversity amongst Vibrio isolates from marine aquaculture systems. Aquaculture, 219(1-4): 9-20. 140 .

$$
\text { الملخص العربي }
$$

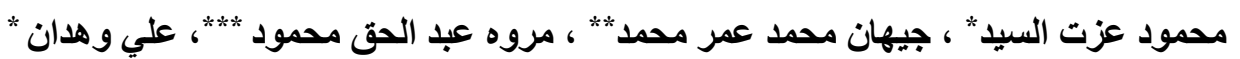

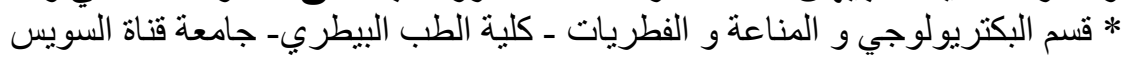

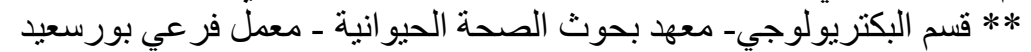
**** طبيب بيطري- معهد الاستزر اع السكي وتكنولوجيا الأسماك - جامعة فناة السويس فيس

استهدفت هذه الدراسه تحديد مدى تواجد ميكروب الفيبريو الجينوليتبكس في بعض أسماك المياه

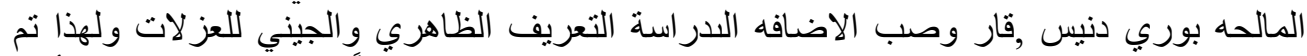

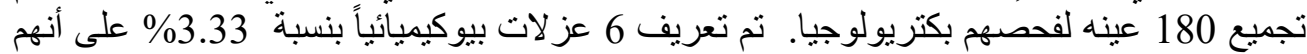

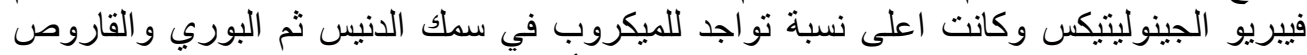

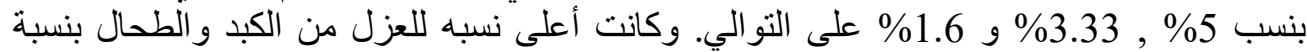

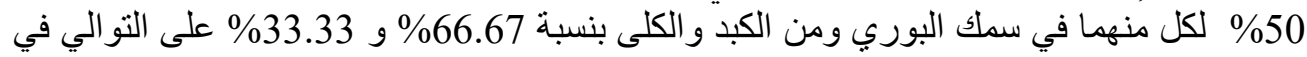

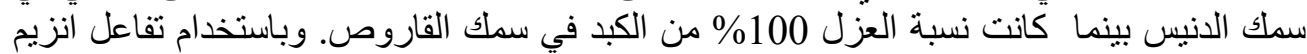

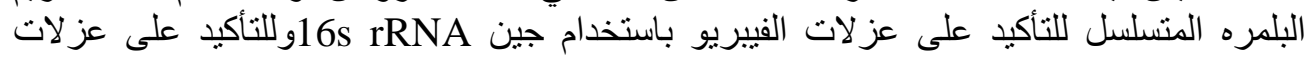

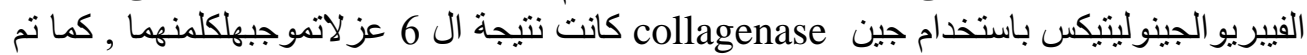
اختبار عز لات الفيبريو الجينوليتيكس لجينات الضراوه tdh , trh وكانت النتيجه سلبيه لكل منهما. 